\title{
Objectives and achievements in the improvement of grain legumes
}

\section{By P. R. Goldsworthy, International Institute of Tropical Agriculture, Ibadan, Nigeria}

The development of high yielding varieties of wheat and rice led to a rapid increase in yields and production of both crops between 1965 and 1970 in a number of developing countries in Asia. By comparison, work to improve varieties of tropical grain legumes continued to suffer from lack of continuity and resources. Without improved varieties the yields of pulse crops as a group remained low compared to the cereals (Litzenberger, I 973). Recognition of the contribution that grain legumes make to protein nutrition in vegetarian diets and of the comparative neglect of these crops, eventually led to proposals for a substantially increased international research effort to overcome the problems of their low productivity (Oram, 1973; Roberts, 1973).

Approximately twenty species of legumes are used for human food. The number and the diversity among them in terms of adaptation and use in different parts of the world made it impractical to embark on the improvement of all of them simultaneously. Priorities had to be set to determine on which species a major research effort should be undertaken. Six species which are grown more extensively than others, were selected and divided into four groups on the basis of the climate to which they are adapted.

To these were added in the Mediterranean climate group, peas (Pisum sativum) and broad beans (Vicia faba) because of their relative importance as food legumes in these environments.

More recently, other, secondary grain legume crops have attracted attention, among them bambara groundnut (Voandzeia subterranea), jackbean and swordbean (Canavalia ensiformis and Canavalia gladiata) lima bean (Phaseolus lunatus) and winged bean (Psophocarpus tetragonolobus).

\section{Organization of research}

The large scale research needed was more than the developing countries could support on their own and international support was provided. It remained to decide how it could be most effectively applied; whether to provide a central facility with responsibility for problems common to a number of the priority grain legume crops or to assign the responsibilities to individual international centres in the regions where a particular crop was grown. The diversity of the crops, the distinct differences in their adaptation to climate, and in the way they are consumed in different parts of the world, eventually determined that the work would be done at separate international centres.

These initiatives, taken in 1970 , led to a substantial increase in research on the improvement of grain legumes in developing countries. The account which follows 
Table I. Climatic adaptation of six legumes and organizations responsible for research into their development

\begin{tabular}{cll}
\multicolumn{1}{c}{ Climate } & \multicolumn{1}{c}{$\begin{array}{c}\text { Crop } \\
\text { Lowland humid tropics }\end{array}$} & $\begin{array}{c}\text { International Centre } \\
\text { responsibility }\end{array}$ \\
$\begin{array}{cl}\text { Seasonally arid tropics } \\
\text { Tropical, intermediate } \\
\text { elevation, temperate }\end{array}$ & $\begin{array}{l}\text { Cowpea (Vigna unguiculata) } \\
\text { Groundnuts (Arachis hypogaea) }\end{array}$ & $\begin{array}{l}\text { ICRISAT } \\
\text { IITA }\end{array}$ \\
ICRISAT \\
$\begin{array}{c}\text { Mediterranean climates, } \\
\text { high elevations }\end{array}$ & Dry beans (Glycine max) & INTSOY/IITA \\
& Chickpea (Cicer arietinum) & CIAT
\end{tabular}

refers mainly to the part of this research that has been done at the international institutes. Many of the examples chosen to illustrate the progress that has been made are taken from results of research on cowpeas at the International Institute of Tropical Agriculture in Nigeria, because it is this part of the total research effort on grain legumes with which I am most familiar.

\section{Research priorities}

Yield and yield stability. From the beginning there has been general agreement that higher and stable yield is the first objective (Litzenberger, 1973; Boulter, 1980) but that some priority should be given to the simultaneous improvement in the quantity and quality of protein in the seed (Bliss, 1980 ). The reason for this order of priorities is evident if we compare what new crop varieties can produce with what the farmer is able to harvest. For example, the best improved varieties of cowpea are capable of producing seed yields of more than $2500 \mathrm{~kg} / \mathrm{ha}$, yet farmers in West Africa usually harvest less than $200 \mathrm{~kg} / \mathrm{ha}$. Insect pests, disease and drought are the principal causes of poor yields and high priority is given to research aimed at finding ways to prevent or limit the loss they cause.

In developing countries host plant resistance is often the only practical way to control diseases and it is also likely to be a component in any successful system for control of insect pests. Faster progress has been made in the genetic control of diseases than of insect pests, and now most of the elite lines in international trials of beans from CIAT and of cowpea from IITA are resistant to the economically important diseases.

Quantity and quality of protein. A farmer will only adopt new varieties if they are as good, or better than the varieties he has; he will not grow them because of their nutritional quality alone. For this reason the breeder has to put yield and yield stability before protein quantity and quality, in the early stages of crop improvement.

Phaseolus vulgaris, the common bean, has been studied more than other grain legumes, and with recent progress in the control of diseases more attention is now being given to the improvement of nutritional value and of consumer acceptance as 
an integral part of the selection procedure at CIAT. For the other grain legumes with a shorter, more limited history of research, yield and yield stability are still the first priority. For example, substantial progress has been made in the last ten years to control diseases of cowpea (Williams, I $977 a, b$; Singh \& Allen, 1980), but insect pests remain a major constraint still to be overcome before a systematic effort can be made to improve nutritional quality.

The nutritional quality of legume seed is complex. Protein content varies within a species and for beans it is between 16 and $33 \%$. Genetic and environmental effects contribute to this variation (Silbernagel, 1971; Bressani, 1973), but the relative importance of each has still to be established for most grain legume species. Most of the protein in the seed is stored in the cotyledons and since this is the largest fraction it offers the best prospect for improvement (Bressani \& Elias, 1980; Boulter, 1980). There is often a negative correlation between yield and protein content, but Leleji et al. (1972) showed that there is sufficient variation in segregating progeny of crosses between high- and low-protein parents to permit selection. CIAT has found the same and one-third of their advanced lines contain more than $28 \%$ protein.

Variations in the composition of the storage proteins is also complex and may reflect differences in the time of accummulation of amino acids. The quality of the protein is determined primarily by the amounts of sulphur amino acids it contains, which varies with genotype and soil (Kang \& Fox, 1975; Bressani \& Elias, 1980). Also there is usually a negative correlation between the amount of sulphur amino acid in the protein and the amount of protein in the seed (Boulter \& Evans, 1975). These relationships add to the difficulties of breeding for nutritional quality. The large environmental effects in particular make careful standardization of field conditions a requirement if comparisons are to be made between locations and seasons.

Anti-metabolites, of which trypsin inhibitors are the most common, affect the digestibility and hence the nutritional quality of legume seed. Their importance varies with species; there are fewer problems of this type in cowpea than in beans and some other legumes. Caution will be needed in the search for insect resistance to ensure that factors such as trypsin inhibitors and tannins, which may confer resistance, are not selected at the expense of nutritional quality.

The nutritional quality of the whole diet may depend as much on the amount of legume consumed as on the quality of the legume protein it contains. In this context, factors that determine consumer acceptance (colour, flavour, seed coat texture and cooking time) may be as important as nutritional quality. Only in diets based on roots and plantains are legumes likely to be the only or dominant source of protein. When we have progressed to the point that yield is more secure, nutritional quality is more likely to be given the priority it deserves. Progress will then depend on the resources that can be devoted to it.

Nitrogen fixation. The genetic improvement of grain legumes is supported at the international centres by parallel research on symbiotic $\mathrm{N}$ fixation. There have been few studies of the populations of rhizobia in tropical soils and therefore little 
is known of their diversity or ability to survive in extreme environments and on problem soils. Little is known also of the specificities involved between different host plants and Rhizobium strains, or of variation in the effectiveness of symbiosis with different crop hosts.

It is known that cowpea and pigeon pea form nodules with a wide range of rhizobia and that inoculation with introduced strains of rhizobia is not usually accompanied by increased yield. In contrast, most varieties of soya bean developed in the United States do not nodulate readily with the rhizobia found in tropical soils. The usual solution is to inoculate the seed with introduced strains of Rhizobium japonicum but in most parts of the tropics inoculants are not available to farmers. As an alternative, soya bean varieties which do not need inoculation are being developed. The same approach might be used with advantage to improve the $\mathrm{N}$ fixation of other grain legumes. Chickpea, like soya bean, is more specific than cowpea and yields can be markedly improved in parts of India if seed is inoculated with an appropriate strain of rhizobia. To eliminate the need for inoculants it seems probable that host plant varieties that are compatible with indigenous rhizobia in these soils could be developed through breeding and selection.

Studies of the accumulation and distribution of $\mathrm{N}$ in cowpeas, show that they are unable to support a high rate of $\mathrm{N}_{2}$ fixation and rapid pod development simultaneously. Also they appear to redistribute $\mathrm{N}$ less efficiently than soya bean and there may be opportunities to improve the fixation and utilization of $\mathrm{N}$ in cowpeas and other grain legumes by selection for early nodulation, continued fixation during pod filling and more efficient retranslocation of $\mathrm{N}$ in the late stages of pod fill (IITA, I 977).

\section{Plant genetic resources}

Through the International Board of Plant Genetics Resources the size and diversity of the collections of food legumes available to breeders has grown dramatically in the past five years and there has been a growing awareness of the vital importance of these collections to further crop improvement. In that time and with the Board's support, the Genetic Resources Unit at IITA, which is only one of the links in the network, has mounted thirty-eight plant collecting missions in eighteen African countries, and has gathered or been given more than 20000 new germplasm accessions. Half of these were food legumes, mainly cowpeas. The cowpea collection which now consists of about I5000 accessions, represents remarkable diversity in physiological adaptation, morphology and reaction to disease and pests, only part of which has been explored and documented.

In it we found many types of multiple resistance to diseases which have since been combined into all the advanced cowpea breeding lines. Almost daily, new and useful genetic characters are discovered in the continued search for resistance to diseases and insect pests.

Similar endeavours have been made at other centres. By 1980 , CIAT had assembled a collection 27000 accessions of Phaseolus sp, of which 24000 are 
P. vulgaris. More than I 1000 had been described and documented for thirty-two characters, including disease reaction and other attributes important to the breeder. ICRISAT has assembled world collections consisting of more than 1200 accessions of chickpea, 9000 of pigeonpea and 8000 accessions of groundnut and is actively exploring and adding to them. ICARDA proposes to maintain world collections of lentils (Lens culinaris) and Vicia beans, and a duplicate set of the ICRISAT collection of chickpea. The four centres have agreed that when any of them mounts a collecting mission it will not only collect the crops in which the sponsoring centre is interested, but also material for the other centres.

The IBPGR participates directly by coordinating the work of the institutes with that of other national centres that form part of the genetic resources network, and by organizing collection of food legumes (and many other economic crop plants) not included in the responsibilities of the institutes. The recent systematic collection in Southeast Asia of Winged bean (Psophocarpus tetragonolobus), a crop of potentially global importance, is an example.

Apart from their value as a source of genetic diversity for the characters that are important now, or that will be in the future, the collections serve to tell us about the evolution of crop plants and their adaptation to the environments and agricultural systems from which they came. This knowledge provides an important background of understanding to crop improvement (Bunting, 1980).

\section{Variety improvement}

Breeding for yields. Not one of the eight grain legume species assigned priority is adapted over the whole diverse range of environments that collectively they occupy, but within individual species there are often cultivars that are precisely adapted to the environments and farming systems in which they are grown.

Photoperiod and night temperature are major determinants of vegetative growth and reproductive ontogony. Their interactions with different genotypes combine to produce a remarkable diversity of plant forms (Evans, I973a; Steele \& Mehra, 1980; Wallace, 1980). In extreme determinate forms which flower early, branches are few and short. Inflorescences form at early nodes and development of new structures ceases abruptly with the formation of a terminal inflorescence on the main shoot and branches, to give an erect habit. At the other extreme, indeterminate forms that are reproductively photoperiod sensitive, may branch profusely if sown sufficiently before reproductively inductive daylengths occur. Even after induction reproductive buds may alternate with branches, unsystematically as in cowpea (Steele, 1972) or systematically as in groundnut (Elston \& Bunting, 1980).

The international centres are using this variation to provide improved varieties for a wide range of environments. To begin with, most or all of the lines distributed for wider testing were selections from the germplasm accessions, but the composition of yield trials and nurseries from CIAT and IITA has changed as more breeder's lines became available. 
To provide varieties that are productive in a wide range of environments, centres have adopted various strategies of recurrent selection based on performance at a number of locations, each representative of a different environment and providing exposure to different diseases and pests (Evans, 1973b; Smithson et al. 1980). The effect has usually been new varieties that show less response to change in environment than the older traditional varieties. This may not always be an advantage. The alternative is to breed varieties for specific environments and cropping systems. As our understanding of response to environment improves it may be profitable to exploit more effectively the advantages of specific adaptation to particular environments.

Precise studies in controlled environments at the University of Reading are a development in this direction. They were designed to examine the effects of daylength and of day and night temperature on selected cowpea cultivars. Different types of adaptive response were found. Some cultivars were insensitive to changes in both daylength and temperature within the normal range that occurs in the tropics; some were sensitive to one or the other and some to both (Summerfield et al. 1980). Other similar studies are now in progress with chickpea.

From related field studies at Ibadan, Littleton et al. (1979a) have described the effects of temperature on the pattern of leaf growth and death, and hence on the development of leaf area of cowpeas. From the same studies they have also described the pattern of accumulation and partition of dry weight and how this is influenced by the incident radiation, the fraction of the radiation intercepted and the efficiency with which it is used (Littleton et al. $1979 b$ ).

With knowledge of this kind, numerical models can be constructed to simulate and predict the effects of a particular environment on the development of leaf area, the accumulation of dry weight and the formation of yield in crops. The models can then help to indicate how crop systems might be developed to make better use of the environment and exploit the capabilities of new varieties. They can at the same time help the breeders to define the characteristics of the varieties required to meet the agronomists' needs (Bunting, 1974).

Control of disease. An important part of the work on grain legumes at the international centres has been to develop varieties that are resistant to most or all of the economically important diseases. Now, most of CIAT's improved lines are resistant to anthracnose (Colletotricum lindemuthianum), common bacterial blight (Xanthomonas phaseoli), rust (Uromyces phaseoli) and bean common mosaic virus (BCMV), (CIAT, 1980). As reliable sources of resistance to some of the diseases has been identified, the search for resistance to others has begun. These include bean golden mosiac virus (BGMV) which can cause substantial losses particularly if it attacks the crop early; also Ascochyta leaf spot (Ascochyta sp), grey leaf spot (Cercospora vanderysti) and web blight (Thanatephorus cucumeris). Similarly resistance to Ascochyta sp and to wilt diseases of chickpea and to virus, fungal and bacterial diseases of groundnuts, are priorities in the research programmes on these crops.

Since relatively little was known of cowpea pathogens in the forest zone of West 
Africa, early work at IITA concentrated first on the identification of the pathogens of major economic importance, and then on the development of control measures. Techniques were developed to create field epidemics and by 1975 about 5000 germplasm accessions had been screened in the field for susceptiblity to anthracnose, cercospora leaf spot $(C$. cruenta), bacterial pustule, rust (Uromyces appendiculatus) and cowpea yellow mosaic virus, as well as the less important diseases $C$. canescens leaf spot, and target spot (Corynespora cassiicala) and bacterial blight (Williams, 1977a,b).

About 100 accessions which combine resistance to the five major diseases were the basis for the establishment in 1974 of an international cowpea disease nursery to identify broad spectrum, stable resistance to distinct populations of pathogens over a wide range of environments.

Early results revealed that the distribution and importance of cowpea pathogens varies with ecological zone. Unlike Ibadan, the principal pathogens in the dry savannah of Africa were found to be scab (Sphaceloma sp.), Septoria leaf spot (S. vignae), brown blotch (Colletotrichum capsici and O. truncatum), bacterial blight (Xanthomonas campestris pv. vignicola) and cowpea aphid-borne mosaic virus (Allen \& Goldsworthy, 1981). Rhizoctonia web blight and the whiteflytransmitted cowpea golden mosaic virus (CGMV) cause extensive damage in the lowland, humid forest zone while, at elevations above $1000 \mathrm{~m}$ Ascochyta is a major problem.

Test locations that are representative of the ecological diversity of West Africa have been selected in Nigeria for disease screening. In the forest zone, early sowing and close spacing (100 $\times 500 \mathrm{~mm}$ ), respectively, help development of uniform natural epidemics of CGMV and web blight that have served to identify moderate levels of combined resistance. At IITA in the savannah transition zone field nurseries are inoculated with pure cultures of the main diseases other than rust, and are screened for resistance to cowpea aphid borne mosaic virus (CAMV) and cowpea mottle virus $(\mathrm{CMeV})$ in screen houses. In the savannah zone 'pre-sown' spreaders inoculated with infected plant material have served to indentify resistance to scab, Septoria, brown blotch and bacterial blight; one line (VITA-4) showed resistance to all four diseases.

Resistant lines have been used as parents in IITA's cowpea breeding programme. Early generation material and more advanced breeding lines are now routinely screened for resistance to six fungal, two bacterial and four viral diseases each year, in environments which favour uniform disease spread. As a result of this work, improved materials emerging from the programme possess sufficient combined disease resistance to make the use of fungicides unnecessary.

Control of insect pests. Disease resistance has been more thoroughly investigated than insect resistance and until now there have been few examples of insect resistant cultivars that have been used to develop new, resistant varieties.

Cowpeas suffer more than most other grain legumes from the damage caused by insect pests and for the present purpose will serve to illustrate the measure being taken to control them. The crop is attacked by a succession of insects, from the 
seedling stage to the stored seed. Damage caused by pre-flowering pests (leafhopper, aphids and leaf beetles) can be controlled. There are many lines resistant to leafhoppers and aphids, while the leaf beetles are important only as vectors of viral diseases, for which virus resistant varieties are the solution.

Much more serious are the flower bud and post-flowering pests (thrip, Maruca and pod bugs). From I 973 onwards studies were conducted of the biology of these pests, and of the use of insecticides to control them. High levels of resistance to both aphids and bruchids were identified, but the resistance found to other pests was more difficult to identify. At the same time, there is encouraging evidence of different mechanisms of resistance, which though separately may give little protection, if combined may give economically useful resistance. However, more precise and dependable methods to identify and recover resistance are needed if progress is to be made.

Thrips (Megalurothrips sjostedi). A few breeding lines derived from crosses with an unimproved line $\mathrm{TVu} 1509$, show some resistance to thrips. It has proved difficult to use the moderate resistance of this single source for breeding because of the variation in the number and distribution of thrips in the field.

Thrips cause the production of ethylene which leads to abscission of flower buds and loss of yield (Fig. I). It was found that the damage they cause can be simulated by applying the synthetic growth regulator ethephon (2-chloroethylphosphonic acid). Most thrips resistant cultivars were also resistant to chemical treatment but there were exceptions; some showed resistance to one or the other, but not both.

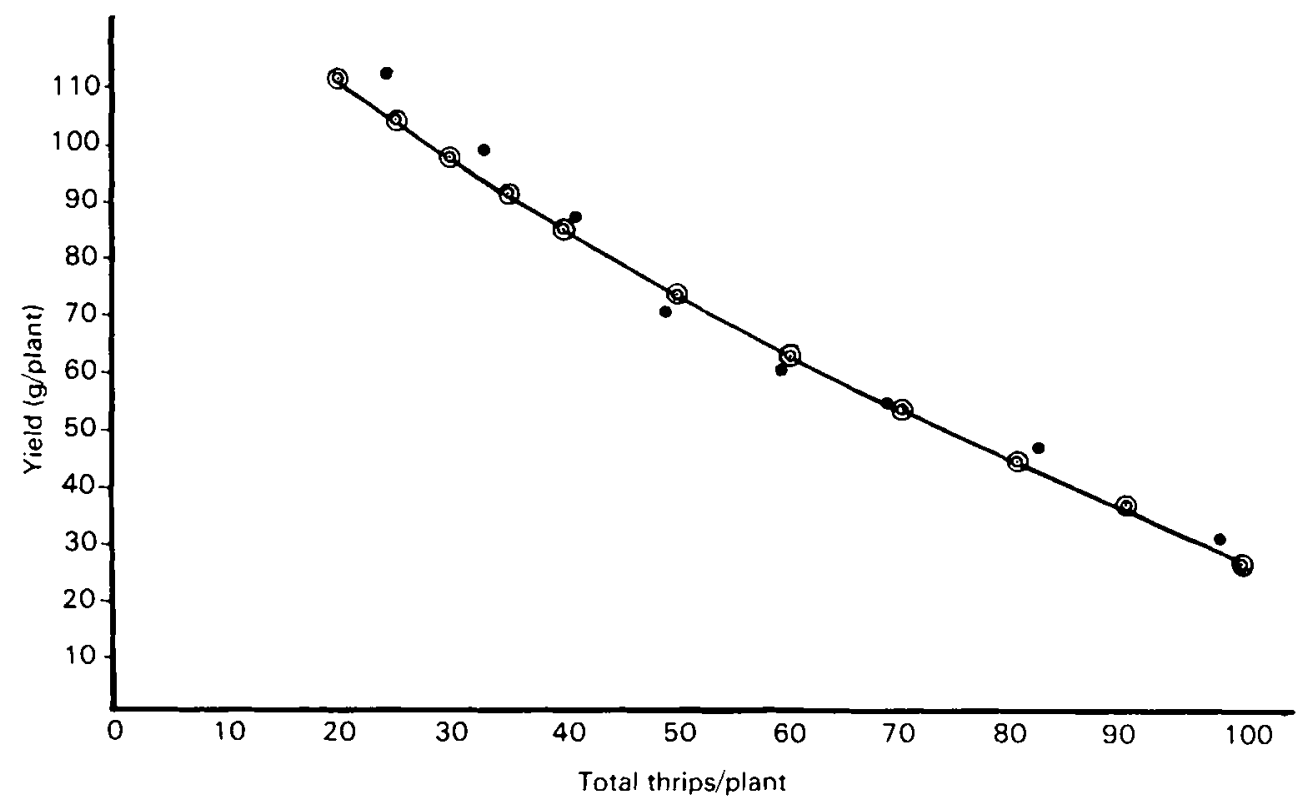

Fig. 1. Relation between numbers of flower thrips and yield of cowpea (IITA, I980). $Y={ }_{1} 41 \cdot 57-1 \cdot 6$ I $T+0.004877^{-2}$. 
This suggests that there may be two mechanisms of resistance, one of them a varietal difference in the way the plant regulates the effect of ethylene.

The other mechanism may be antibiosis. After seven days the number of progeny produced by fifteen adult thrips on TVu ${ }_{1509}$, the resistant cultivar, was 774; on Prima, a line that is susceptible to thrips, there were 1707 progeny (IITA, I979). It is interesting to note that TVu I 509 is resistant to thrips and to ethylene. One of the best lines derived from it, TVx 3236-o I G, shows similar resistance to thrips, but it is sensitive to ethylene. If there prove to be two separate mechanisms then the aim should be to combine them in future selections.

Pod borer (Maruca testulalis). A field technique for assessing the resistance of genetically uniform lines to Maruca is being developed (IITA, $198 \mathrm{r} a, b$ ). It is based on estimates of damage to shoots, flowers, pods and seed, which are then combined to give a damage index. The method has shown consistent differences between TVu 946, the most resistant line available; VITA-3, which is susceptable and a range of varieties with intermediate resistance. Flowers are a favoured site for oviposition and larval feeding. The resistant line supports a consistently smaller population of larvae in the flowers than VITA-3.

A screenhouse technique is being developed for the evaluation of resistance in single plants of segregating populations.

Pod bugs. Several species of hemipteran bugs (Clavigralla shadebi, C. tomentosicollis, Riptortus dentipes, Aspavia armigera, Nezara viridula and Anoplocnemis curvipes) can cause severe damage and yield loss on cowpeas. Fig. 2 shows the

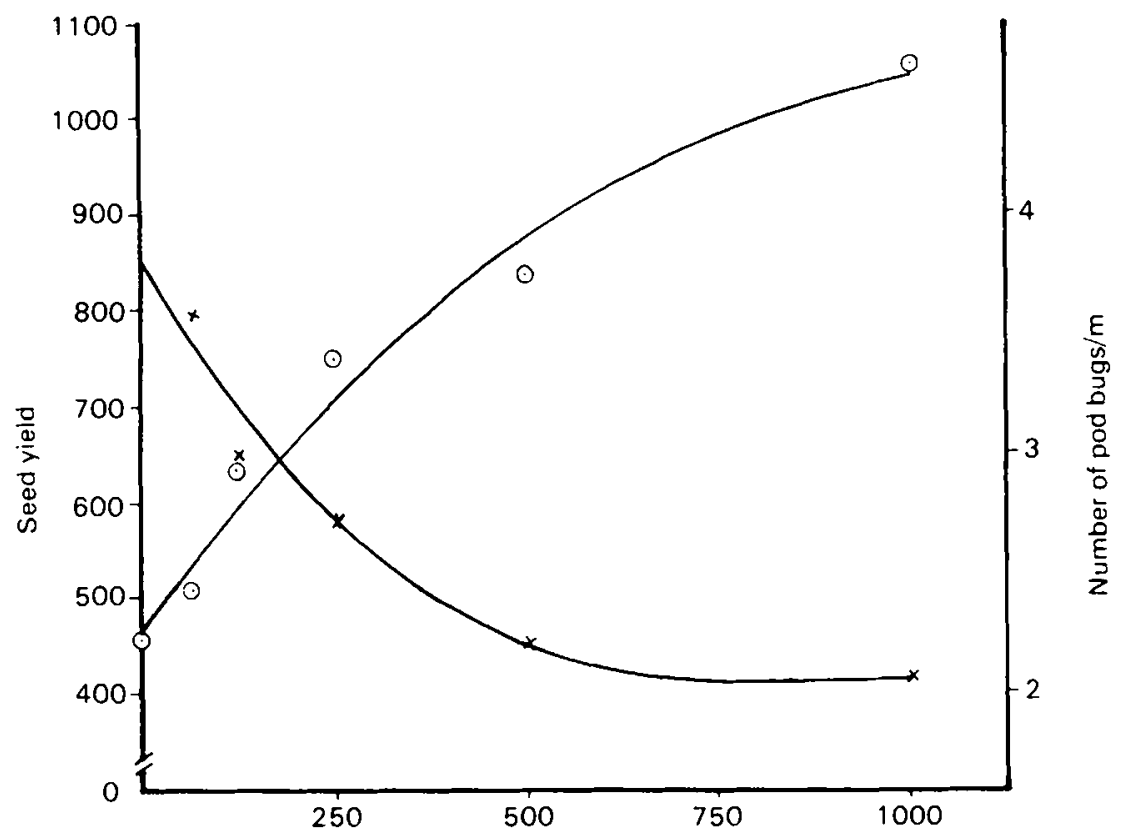

Fig. 2. Effect of the insecticide endosulfan on the number of pod bugs ( $x$ ) and yield of cowpea. (IITA, I 980). 
effect of insecticide treatments on the numbers of pod-bugs and the yield of cowpea. Field observations show that $C$. tomentosicollis adults invade cowpea fields in large numbers in the seasonally arid savannas of West Africa. An untreated field in Nigeria had more than thirty adults (mainly $C$. tomentosicollis) $/ \mathrm{m}$ row and hundreds of nymphs. Surveys of field populations to determine whether these are typical of the entire cowpea growing area are being carried out at several locations in West Africa. So far wild hosts from which the large invasion of adult $C$. tomentosicollis may come, have not been identified (IITA, 1981 $b$ ). Meantime in laboratory tests it has been shown that resistance may be associated with pod colour. There were fewer feeding punctures on dark green pods than on light green pods; and fewer still on pods in which dark green pigment (seen on sutures) and purple pigment were combined. The same relative rating of these three colours was found in laboratory, screenhouse and field tests (Table 2).

More recently there is some indication that there may be lines with an active antibiosis, on which the pod bug nymphs do not survive.

Storage bruchid (Callosobruchus maculatus). Bruchids provide a final example of host plant resistance, and of an interesting opportunity to combine two mechanisms of resistance that could together eliminate the extensive damage that occurs to cowpeas in store. Caswell (1973) estimated that the damage caused by the cowpea bruchid represented a loss of about 55000 tons of cowpeas annually in Nigeria alone. At today's prices this is more than $\$ 30$ million/year.

Resistance to cowpea bruchid was first identified at IITA in an accession TVu 2027 from Northern Nigeria and subsequently demonstrated to be associated with an above normal content of trypsin inhibitor in the seed (Baker, 1979). Since all cowpeas are cooked before being eaten, the trypsin inhibitor does not detract from the nutritional value.

The natural rate of increase of bruchids on a susceptible line, Ife Brown, is three times that on TVu 2027 (Fig. 3), and the median time from egg to adult is shorter ( 24 d compared to 3 I $d$ on TVu 2027) (IITA, 1981 b). Unfortunately TVu 2027 , the only known source of resistance, is extremely susceptible to cowpea yellow mosaic virus. This means that to be useful bruchid resistance must be transferred to virus resistant and agronomically better plants. The mode of inheritance of the resistance has been studied and from crosses between TVu 2027 and virus

Table 2. Resistance to pod bugs

$\begin{array}{lllll}\text { Cultivar } & \begin{array}{l}\text { Pod colour } \\ \text { Light green }\end{array} & \overbrace{\text { Test } 1} & \text { Test } 2 & \text { Field } \\ \text { Ife Brown } & 4 \cdot 3 & 2 \cdot 3 & 1 \cdot 9 \\ 8 \text { Screenhouse } & \text { No. of adults/m row } \\ \text { TVx } 3878-2-1 & \begin{array}{l}\text { Dark green } \\ \text { Dark green } \\ \text { t purple }\end{array} & 3.5 & 0.9 & 1 \cdot 2 \\ \text { SE } & & 0.7 & 1 \cdot 2 & 0.7 \\ & & 0.71 & 0.10 & 0.14\end{array}$




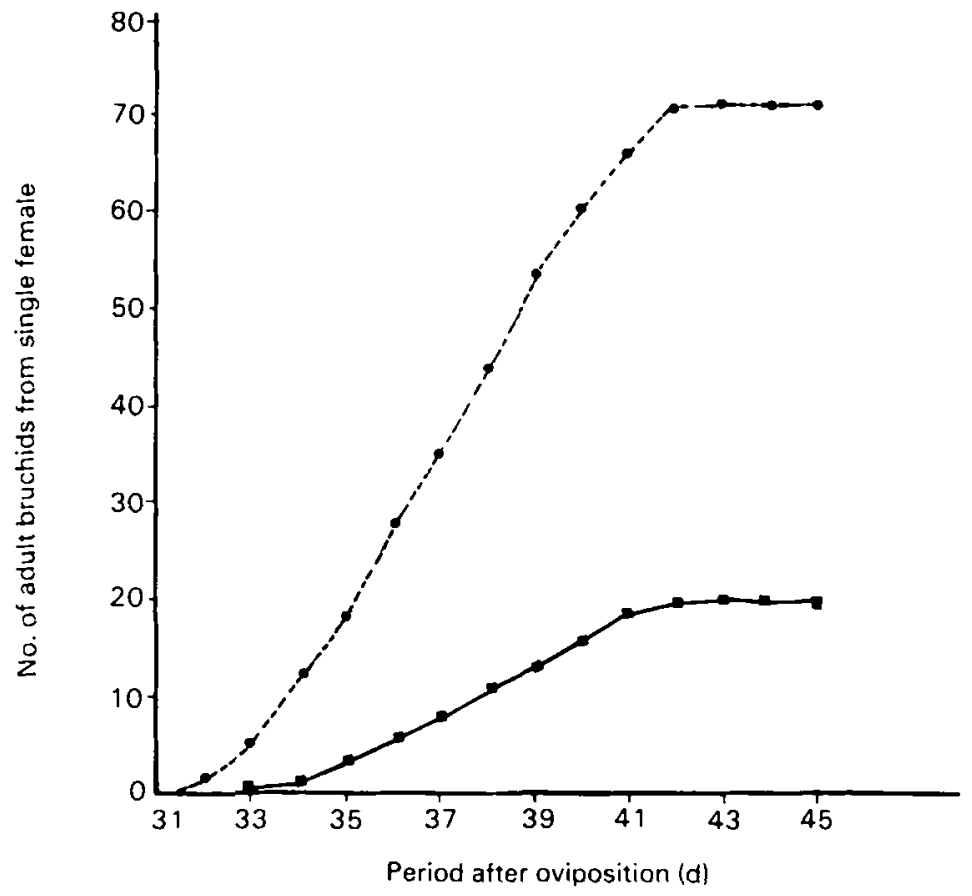

Fig. 3. Number of adult bruchids derived from a single female on susceptable (Brown) and resistant ( - ; T T 2027) strains of cowpea seed (IITA, 1980).

Table 3. Effect of seed and pod resistance separately and combined in suppressing the population of bruchids and preventing damage

\begin{tabular}{|c|c|c|c|c|c|c|c|}
\hline Cultavar & Eggs/pod & Hatch & $\begin{array}{c}\text { No. } \\
\text { larvae } \\
\text { entered }\end{array}$ & $\begin{array}{l}\text { Adults } \\
\text { emerged }\end{array}$ & $\begin{array}{c}\text { Survival } \\
(\%)\end{array}$ & $\begin{array}{l}\text { Damaged } \\
\text { seed }(\%)\end{array}$ & $\begin{array}{l}\text { Exit } \\
\text { Holes }\end{array}$ \\
\hline Susceptible & 17 & 100 & 16 & I I & 64 & 63 & 8.8 \\
\hline resistant seed & 17 & 100 & 15 & 3 & 19 & 24 & 1. 6 \\
\hline e resistant pod & I 7 & 99 & 14 & $\stackrel{1}{-}$ & $\begin{array}{l}7 \\
6\end{array}$ & $\begin{array}{l}7 \\
6\end{array}$ & $\begin{array}{l}0.7 \\
0.9\end{array}$ \\
\hline $\begin{array}{l}\text { f combined seed } \\
\text { resistance }\end{array}$ & -- & - & 一 & 一 & 2 & -- & - - \\
\hline
\end{tabular}

resistant lines three progeny lines have been selected that have large seed and resistance to both virus and bruchids.

In north and south America another pest (Chalcodermus aeneus) punctures the pod and deposits eggs on the inner pod wall. It is a serious field pest, but not a storage pest. Several lines of cowpeas have been developed that are resistant to Chalcodermus. One of these, Worthmore, was examined at IITA and found to possess pod resistance to Callosobruchus maculatus. In two separate tests the survival of Callosobruchus was less than $20 \%$ of that found on normal, susceptible lines. 
The seed resistance found in TVu 2027 and the pod resistance found in Worthmore are believed to be entirely separate mechanisms of resistance. If they could be combined they would suppress more than $98 \%$ of the bruchid population (Table 3). In the dry savannah areas of West Africa where cowpeas are traditionally stored in pods, varieties that possess both types of resistance would virtually eliminate the present large and costly loss of food.

The future prospects for significantly increased production of cowpea in West Africa will rest more on the success of measures to control this succession of pests, than perhaps any other factor.

The examples given of research on cowpea illustrate the main task of breeders who seek to improve the contribution of grain legumes to human diets. Their first task is to increase and stabilize yield by producing new varieties adapted to particular environments or crop systems, and to control factors that cause loss of yield, particularly the damage caused by diseases and pests.

Breeders may need to ensure that the content of protease inhibitors, haemaglutanins and tannins, which may increase as a result of selection for resistance to pests and diseases, does not do so to levels that adversely affect the digestibility and nutritional quality of the seed.

In the new varieties it may be more important at present to maintain or improve the factors that determine consumer acceptance (colour, flavour, seed coat texture and cooking characteristics) than to attempt to alter the content of protein or the amino-acid composition of the seed.

\section{REFERENCES}

Allen, D. J. \& Goldsworthy, P. R. (1981). Proc. int. Conf. Trop. Crop Protection. Lyon, France: PROMOLYYN.

Baker, A. M. R. (1979). Protease inhibitors and the biochemical basis of insect resistance in Vigna unguiculata (L) Walp. PhI) thesis, University of Durham.

Bliss, F. A. (1980). In Advances in Legume Science, p. I79 [R. J. Summerfield and A. H. Bunting, cditors]. London: HMSO.

Boulter, D. ( 1980 ). In Advances in Legume Science, p. 127 [R. J. Summerfield and A. H. Bunting, editors]. London: HMSO.

Boulter, D. \& Evans, I. M. (1975). Proc. IITA Collab. Mtg Grain Legume Imprv., p. I 15. Ibadan, Nigeria: IITA.

Bressani, R. (1973). In Potentials of field beans and other legumes in Latin America, p. 17. Series seminars No. 2E. Cali, Colombia: Centro Internacional de Agricultura Tropical.

Bressani R. and Elias, L. G. (1980). In Advances in Legume Science, p. I 35 [R. J. Summerfield and A. H. Bunting, editors]. London: HMSO.

Bunting, A. H. (1974). Weather 30, 3 12.

Bunting, A. H. (1980). In Crop Genetic Resources in Africa, p. 14. Ibadan, Nigeria: Association for the Advancement of Agricultural Sciences in Africa and the International Institute of Tropical Agriculture.

Caswell, G. H. (1 973). Trop. Stored Prod. Inf. $25,19$.

Centro Internacional de Agricultura Tropical (1980). 1979 CIAT Annual Report. Cali, Colombia: CIAT.

Elston, J. \& Bunting, A. H. (1980). In Advances in Legume Science, p. 37 [R. J. Summerfield and A. H. Bunting, editors]. London: IMMSO. 
Evans, A. M. (1973a). In Nutritional Improvement of Food Legumes by Breeding, p. 107 [M. Milner, editor]. New York: Protein Advisory Group of the United Nations.

Evans, A. M. (1973b). In Potentials of Field Beans and other Legumes in Latin America, p. 279. Series seminars No. 2 E. Cali, Colombia: Centro Internacional de Agricultura Tropical.

International Institute of Tropical Agriculture (1977). Annual Report 1976. Ibadan, Nigeria: IITA.

International Institute of Tropical Agriculture (1979). Research Highlights 1978. Ibadan, Nigeria: IITA.

International Institute of Tropical Agriculture (1980). Annual Report 1979. Ibadan, Nigeria: IITA.

International Institute of Tropical Agriculture (1981a). Annual Report I980. Ibadan, Nigeria: IITA.

International Institute of Tropical Agriculture $(198 \mathrm{I} b)$. Research Highlights 1980 . Ibadan, Nigeria: IITA.

Kang, B. T. \& Fox, R. L. (1975). Proc. IITA Collab. Mtg Grain Legume Imprv. p. I05. Ibadan, Nigeria: IITA.

Leleji, O. I., Dickson M. H., Crowder, L. V. \& Bowlee, J. E. (1972). Crop Sci. 12, 68.

Littleton, E. J., Dennett, M. D., Elston, J. \& Monteith, J. L. (1 979a). F. Agric Sci., Camb. 93, 291.

Littleton, E. J., Dennett, M. D., Monteith, J. L. \& Elston, J. (I 979b). F. Agric Sci., Camb 93, 309.

Litzenberger, S. C. (1973). In Potentials of Field Beans and other Legumes in Latin America, p. 3. Series seminars No. 2E. Cali, Colombia: Centro Internacional de Agricultura Tropical.

Oram, P. (1973). In Nutritional Improvement of Food Legumes by Breeding, p. 163 [M. Milner, editor]. New York: Protein Advisory Group of the United Nations.

Roberts, L. M. (1973). In Nutritional Improvement of Food Legumes by Breeding, p. 3 [M. Milner, editor |. New York: Protein Advisory Group of the Linited Nations.

Silbernagel, M. J. (197I). In Proc. Ioth Dry Beans Research Conf. Agricultural Research Service $74^{-5}$, p. 70. Washington: USDA.

Singh, S. R. \& Allen D. J. (1980). In Advances in Legume Science, p. 419 [R. J. Summerfield and A. H. Bunting, editors]. London: HMSO.

Smithson, J. B., Redden, R. J. \& Rawal, K. M. (1980). In Advances in Legume Science, p. 445 [R. J. Summerfield and A. H. Bunting, editors]. London: HMSO.

Steele, W. M. ( 1972 ). Cowpeas in Nigeria. PhD thesis, Liniversity of Reading.

Steele, W. M. \& Mehra, K. L. (1980). In Advances in Legume Science, p. 393 [R. J. Summerfield and A. H. Bunting, editors]. London: HMSO.

Summerfield, R. J. Minchin, F. R., Roberts, E. H. \& Hadley (1980). Proc. Conf. Potential Productivity Field Crops Under Different Environments. Manila, Philippines: International Rice Research Institute.

Wallace, D. H. (1980). In Advances in Legume Science, p. 349 [R. J. Summerfield and A. IH. Bunting, editors]. London: H.MSO.

Williams, R. J. (1977a). Trop. Agric., Trin. 54, 53.

Williams, R. J. ( $1977 b$ ). Trop. Agric., Trin. 54, 61. 